\title{
Tropical Animal Health and Production
}

This Journal publishes the results of original research, investigation and technology in the fields of animal disease and animal production which may lead to improved health and productivity of livestock and better utilisation of animal resources in developing countries, particularly in tropical and sub-tropical zones.

Published quarterly in February, May, August and November.

Volume 14, 1982

Annual subscription $£ 28.00 \$ 64.00$

ISSN 0049-4747

\section{British Poultry Science}

\section{Edited by $K N$ Boorman}

This Journal will appeal to all who are interested in poultry research or in the industry which it serves. The editorial policy is to cover the whole field of poultry science and to publish papers on original research directed at any branch of poultry. The Journal draws together papers of high standing in different disciplines but with a common interest in domestic poultry dealing with physiology, nutrition, genetics, etc. of the bird and the characteristics of its products. Book reviews are also published.

Published bi-monthly beginning January.

Volume 23, 1982

Annual subscription $\mathrm{f42.00 \$ 103.00}$

ISSN 0007-1686

Orders for the above, with the correct remittance, to:

Subscriptions Dept., Longman Group Ltd., Fourth Avenue, Harlow, Essex.

\section{Longman}


Illustrations. The same material should not normally be presented in tables and figures. Legends should be typed on a separate sheet.

(a) Diagrams should be drawn in Indian ink, about twice the size of the finished block, on Bristol board, stout tracing paper or plastic film. Photographed diagrams are also accepted. Lettering inside the framework of the diagram should be avoided as far as possible but if unavoidable it should be included on a fly-leaf. Marginal lettering should be inserted lightly in pencil on the original diagram or on a fly-leaf.

(b) Photographs intended for half-tone reproduction should be on glossy paper. They will be accepted only if found necessary by the Editors.

(c) Colour plates are unlikely to be accepted unless authors bear the cost.

Tables should be as simple and as few as possible. Each table should be typed on a separate sheet.

Abstract. Every article should have a short abstract (not more than 250 words) complete in itself and understandable without reference to the paper. The abstract will be printed at the beginning of the paper.

References. Only papers closely related to the author's work should be referred to; exhaustive lists should be avoided. The arrangement of references should be as in recent papers in Animal Production; details are given in the notes for guidance.

Proofs are supplied once and must be returned corrected to the Editors within 3 days. Only essential corrections should be made.

Reprints. Twenty-five reprints of each paper will be supplied free to authors on request. Further copies may be purchased if the order is sent at the proof-stage.

Animal Production is published six times a year in two volumes. Annual subscription is $£ 49.00$ (or $\$ 112.00$ in the USA and Canada) and the price for a single part is $£ 9.00$ (or $\$ 21.00$ ) net.

Proceedings of the British Society of Animal Production (New Series) ceased publication in 1975 and the material is now published as a separate section in the June issue of Animal Production.

Business matters, including regular subscriptions and sales (current and back numbers of the Journal and the Proceedings), should be addressed to: Longman Group Limited, Subscriptions (Journals) Department, Fourth Avenue, Harlow, Essex, England CM19 5AA.

\section{Senior Editor}

J. A. F. Rook, Agricultural Research Council

\section{Editors}

P. J. Avery, University of Reading

R. C. Campling, Wye College, University of London

M. F. Fuller, Rowett Research Institute

C. J. M. Hinks, Animal Breeding Research Organisation

R. B. Land, Animal Breeding Research Organisation

T. L. J. Lawrence, University of Liverpool

A. M. Raven, Department of Agriculture and Fisheries for Scotland

J. H. B. Roy, National Institute for Research in Dairying

A. J. F. Webster, University of Bristol

\section{Technical Editors}

Jill M. Read

P. D. Wilson 


\section{CONTENTS}

PAGE

TAylor, A. J., Cole, D. J. A. and Lewis, D. Amino acid requirements of growing pigs. 3. Threonine

Leibholz, Jane. Utilization of casein, fish meal and soya bean proteins in dry diets for

pigs between 7 and 28 days of age .
Elliot, J. I., Lodge, G. A., Fortin, A. and Larmond, Elizabeth. Reproductive performance, growth and carcass characteristics of gilts mated at puberty, restricted in food intake during gestation and slaughtered post-partum .

Gonzalez, J. S., Robinson, J. J., McHattie, I. and Fraser, C. The effect in ewes of source and level of dietary protein on milk yield, and the relationship between the intestinal supply of non-ammonia nitrogen and the production of milk protein

Hamra, A. M. and Bryant, M. J. The effects of level of feeding during rearing and early pregnancy upon reproduction in young female sheep . . . . . . . 41

Beilharz, R. G. The effect of inbreeding on reproduction in mice . . . . .

Gordon, F. J. The effect of pattern of concentrate allocation on milk production from autumn-calving heifers

Baishya, N., Morant, S. V., Pope, G. S. and Leaver, J. D. Rearing of dairy cattle. 8. Relationships of dietary energy intake, changes in live weight, body condition and fertility

Chestnutt, D. M. B. The effect of weaning date on the performance of autumncalving, single-suckled cows . . . . . . . . . . . . . . .

Charles, D. D. Meat tenderness and palatability of Swamp buffalo and four breeds of cattle

Kebede, B. and Galal, E. S. E. A study of body weight from birth to 1 year of age in European-zebu crossbred cattle in Ethiopia

Steen, R. W. J. and McIlmoyle, W. A. An evaluation of red clover silage for beef

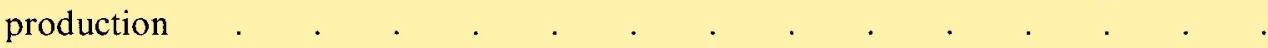

Horn, G. W., Armbruster, S. L. and Sims, P. L. A note on supplemental protein and monensin for steers wintered on dormant native range . . . . . . . .

Lindeman, M. A., Brigstocke, T. D.A. and Wilson, P. N. A note on the response of growing rabbits to varying levels of sodium hydroxide-treated straw 